\title{
Treatment of Bone Metastases in Patients with Advanced Breast Cancer
}

\author{
Michael Gnant ${ }^{\mathrm{a}}$ Marija Balic $^{\mathrm{b}} \quad$ Edgar Petru $^{\mathrm{c}}$ Wolfgang Raunik $^{\mathrm{d}}$ \\ Guenther G. Steger ${ }^{f}$ Ingeborg M. Watzke ${ }^{\mathrm{g}}$ Thomas Brodowicz ${ }^{\mathrm{h}}$ \\ aDepartment of Surgery, Comprehensive Cancer Center Vienna, Medical University of Vienna, \\ bDepartment of Internal Medicine, Division of Oncology, \\ 'Department of Obstetrics and Gynecology, Division of Gynecology, Medical University of Graz, \\ 'Institute of Radiooncology, General Hospital of Klagenfurt, \\ eDepartment of OB/GYN, Comprehensive Cancer Center Vienna, \\ fDepartment of Medicine I, Clinical Division of Oncology, Medical University of Vienna, \\ ${ }^{9}$ Department of Oral and Maxillofacial Surgery SMZ Ost Donauspital, Vienna, \\ ${ }^{h}$ Department of Medicine I, Clinical Division of Oncology, Medical University of Vienna, Austria
}

\author{
Christian F. Singer ${ }^{\mathrm{e}}$
}

\section{Keywords}

Breast Cancer - Metastatic bone disease - Bisphosphonates .

Denosumab - Osteonecrosis of the jaw

\section{Summary}

Bone metastases are usually associated with a variety of skeletal related events (SREs), a term covering both complications (pathological fractures, spinal cord compression) and the need for therapeutic intervention (radiotherapy, surgery to bone) for painful bone lesions and/or lesions carrying a high risk of fracture by which the patient's quality of life, functioning, and independence may be compromised. In view of the availability of improved therapeutic approaches for oncological diseases and the resulting improvements of median overall survival, the aim of preventing and delaying the occurrence of SREs becomes more important. To avoid, wherever possible, therapies requiring hospitalization, is another relevant goal. In recent years, bisphosphonates, along with available tumor-specific medication (chemotherapy, hormone therapy), constituted the standard of care for preventing skeletal complications in treating patients with bone metastases. Recently, a therapeutical alternative with potentially superior efficacy has been found in denosumab, a fully human monoclonal antibody that binds to the receptor activator of nuclear factor$\kappa B$ ligand (RANKL), thus preventing osteoclast-mediated bone resorption and specifically interfering with bone metabolism.

\section{Schlüsselwörter}

Mammakarzinom · Knochenmetastasen · Bisphosphonate . Denosumab $\cdot$ Kieferosteonekrosen

\section{Zusammenfassung}

Knochenmetastasen gehen mit einer Reihe von Skelettereignissen (SREs, skeletal related events) einher, wobei unter diesem Begriff sowohl Komplikationen (pathologische Frakturen, Rückenmarkkompression) als auch die Erfordernis einer therapeutischen Intervention (Radiotherapie, operative Eingriffe/chirurgische Intervention am Knochen) im Falle schmerzhafter u/o frakturgefährdeter Knochenläsionen subsumiert werden, welche die Lebensqualität und das Funktionsniveau der Betroffenen negativ beeinflussen können. In Anbetracht verbesserter therapeutischer Möglichkeiten für onkologische Erkrankungen und der damit assoziierten Verlängerung des durchschnittlichen Gesamtüberlebens muss der Prävention und Verzögerung des Auftretens von SREs und der Vermeidung krankenhausabhängiger Therapien besondere Bedeutung beigemessen werden. In den vergangenen Jahren waren Bisphosphonate in Hinblick auf die Vermeidung von Skelettkomplikationen zusätzlich zu den verfügbaren tumorspezifischen medikamentösen Therapieverfahren (Chemotherapie, Hormontherapie) der Standard in der Behandlung von Patienten mit ossären Metastasen. Mittlerweile steht mit Denosumab, einem vollhumanen monoklonalen Antikörper, der über seine Bindung an den «receptor activator of nuclear factor- $\mathrm{B} B$ »-Liganden (RANKL) die osteoklastenmediierte Knochenresorption verhindert und dadurch spezifisch in den Knochenstoffwechsel einzugreifen vermag, eine zielgerichtete therapeutische Alternative zur Verfügung.

\section{KARGER \\ Fax +497614520714 \\ Information@Karger.de}

www.karger.com (c) 2012 S. Karger GmbH, Freiburg

$1661-3791 / 12 / 0072-0092 \$ 38.00 / 0$

Accessible online at:

www.karger.com/brc
Prof. Dr. med. Michael Gnant, MD, FACS

Medizinische Universität Wien, Universitätsklinik für Chirurgie

Comprehensive Cancer Center Vienna

Währinger Gürtel 18-20, 1090 Wien, Austria

Tel. +43 1 40400-5646, Fax -7603

michael.gnant@meduniwien.ac.at 


\section{Bone Metastases and Their Consequences}

Bone metastases are frequent in patients with oncological diseases and are often associated with serious consequences ranging from increased morbidity, loss of autonomy, functional dependence, poor quality of life to a higher mortality rate and high medical costs [1, 2]. In 2008, the number of breast cancer cases in Europe was estimated at 420,845, accounting for $28 \%$ of all cancer cases (excluding nonmelanoma skin cancer cases) among women [3]. In the Western world, $75 \%$ of women with breast cancer are postmenopausal [4].

Up to $80 \%$ of patients with metastatic breast cancer patients develop bone metastases resulting in local bone destruction and skeletal complications [5, 6]. In the advanced stage of breast cancer $65-75 \%$ of patients eventually develop bone metastases [7], often accompanied by skeletal complications, particularly in patients not treated with a bone-active agent. Overall treatment success has become excellent: $89 \%$ of patients survive at least 5 years from the initial diagnosis [8].

Bone metastases may have serious and severely debilitating consequences with spinal cord compression [9], requiring radiotherapy and surgical interventions at the affected site [10]. Across all tumor entities the most frequent skeletal related events (SREs) are pathological fractures, the highest rate of which occurs in patients with advanced breast cancer.

A randomized, placebo-controlled study of pamidronate in advanced breast cancer showed that $64 \%$ of patients treated with placebo developed one or more SREs in the course of a 2-year follow-up, while the results of an analogous study of zoledronic acid (4 mg q4w) vs. placebo was $49.6 \%$ of patients in the placebo group after a 1-year follow-up $[11,12]$. In addition, the retrospective analysis of a study showed that breast cancer patients with a previous skeletal complication had a higher risk of subsequent SREs: the risk of subsequent events was twice as high $(68 \%)$ in patients that had suffered at least 1 SRE before inclusion in the study as it was in patients with no previous SRE [13]. Cumulative costs of the treatment of SREs in breast cancer patients are considerable [14] and various studies have shown that pathological fractures carry a higher risk of mortality [15]. Randomized controlled studies that correlate the occurrence of skeletal complications with the overall mean time of survival of oncology patients emphasize the significance of SRE prevention. Particularly in the case of successful palliative therapy it is of decisive importance for the patient to prevent pathological fractures in order to sustain functionality and ensure a minimum of pain burden.

Improved therapeutical measures can extend the average period of survival of breast cancer patients, which logically leads to increasing 'time at risk of skeletal complications'. SRE prevention is thus essential to ensure that a good quality of life is sustained as long as possible in the treatment continuum. For all these reasons, SREs are currently accepted as valid endpoint parameters in studies on the effectiveness of antiresorptive substances.

\section{Bone Metabolism}

As living tissue, healthy bones undergo constant remodeling, which is the consequence of continuous self-regulation by a sensitive balance between bone loss due to osteoclasts and bone formation by osteoblasts. Once this balance shifts towards bone resorption, bone mass is lost in the long run, mostly due to an increase in osteoclast activity [16]. The most important stimulator of osteoclast activity is the receptor activator of nuclear factor-кB (RANK) ligand (RANKL) [17, 18]. RANKL is essential for maturation, functioning, and survival of osteoclasts. It binds to RANK, its receptor on the osteoclast precursor cells and causes them to differentiate. RANKL is endogenously controlled by a second key regulator, osteoprotegerin (OPG), a soluble receptor formed and secreted, like RANKL, by osteoblasts [19]. By binding to RANKL, OPG neutralizes the RANKL's interaction with RANK and ultimately inhibits the formation and function of new osteoclasts $[17,19]$. Tumor cells express different growth factors that stimulate the production of RANKL [20]. The increasing expression of RANKL in the proximity of the tumor leads to the proliferation of osteoclasts, activates them and promotes their survival, and so results in osteolytic lesions [21], which, on account of bone resorption, result in the release of growth factors such as transforming growth factor- $\beta$ (TGF $\beta)$, insulinlike growth factors (IGFs), fibroblast growth factors (FGFs), platelet-derived growth factor (PDGF) and bone morphogenetic proteins (BMPs) [20, 22]. These, in turn, stimulate the production of the parathyroid hormone-related peptide (PTHrP) or directly promote tumor growth [20]. At the same time, bone destruction increases the local extracellular calcium concentration, which also contributes to tumor growth and the production of PTHrP [22].

\section{Standard of Care}

Until recently, bisphosphonates provided the only standard of care in the prevention and treatment of SREs. They have been investigated in a number of placebo-controlled studies as to their efficacy in preventing SREs in patients with advanced oncological disease (table 1, pamidronate [11]; ibandronate [23, 24]; zoledronic acid [25, 26]).

\section{Bisphosphonates: Mechanism of Action and Clinical Data}

Irrespective of their route of administration bisphosphonates accumulate on the bone surface and are resorbed by osteoclasts in the bone matrix, this resorption being particularly 
Table 1. Studies on bone-targeted therapy in patients with breast cancer and bone metastases

\begin{tabular}{|c|c|c|c|}
\hline Reference & $\mathrm{n}$ & Treatment & Results \\
\hline Conte et al., 1996 [31] & 295 & $\begin{array}{l}\text { placebo vs. pamidronate } \\
\text { ( } 45 \mathrm{mg} \text { i.v. every } 3 \text { weeks) }\end{array}$ & $\begin{array}{l}\text { reduced time to progression of disease ( } 168 \text { days vs. } 249 \text { days; } p=0.02 \text {; } \\
1 \text { by } 48 \% \text { ) } \\
\text { pain relief ( } 30 \text { vs. } 44 \% \text { of patients; } p=0.025 \text { ) }\end{array}$ \\
\hline Lipton et al., 2000 [11] & 751 & $\begin{array}{l}\text { pooled analysis of the Hortobagyi et al. } \\
{[32] \text { and Theriault et al. [33] trials }}\end{array}$ & $\begin{array}{l}\text { reduction in skeletal complications }(64 \text { vs. } 51 \% ; \mathrm{p}<0.001) \\
\text { reduction mean SMR ( } 3.7 \text { vs. } 2.4 ; \mathrm{p}<0.001)\end{array}$ \\
\hline Body et al., 2003 [23] & 466 & $\begin{array}{l}\text { placebo vs. ibandronate } \\
\text { (6 mg i.v. every } 3-4 \text { weeks; } 2 \text { years) }\end{array}$ & $\begin{array}{l}\text { reduction SMPR by } 20 \% \text { ( } 1.48 \text { events vs. } 1.19 \text { events per patient year; } \\
\mathrm{p}=0.004) \\
\text { prolonged time to first SRE ( } 33.1 \text { weeks vs. } 50.6 \text { weeks; } \mathrm{p}=0.018) \\
\text { reduced number of new bone events by } 38 \%\end{array}$ \\
\hline Body et al., 2004 [24] & 564 & $\begin{array}{l}\text { placebo vs. ibandronate } \\
\text { (50 mg/ day; oral; } 96 \text { weeks) }\end{array}$ & $\begin{array}{l}\text { reduction mean SMPR }(1.18 \text { vs. } 0.95 ; \mathrm{p}=0.004) \\
\text { reduced risk of SRE }(\mathrm{HR}=0.62 ; \mathrm{p}=0.0001) \\
\text { reduced mean number of events requiring surgery }(0.47 \mathrm{vs.} 0.53 \text {, } \\
\mathrm{p}=0.037) \text { or radiotherapy }(0.73 \text { vs. } 0.98, \mathrm{p}<0.001) \\
\text { no significant difference in percentage of patients with SRE } \\
\text { or time to SRE }\end{array}$ \\
\hline Rosen et al., 2001 [25] & 1,648 & $\begin{array}{l}\text { pamidronate ( } 90 \mathrm{mg} \text { i.v. }) \\
\text { vs. zoledronic acid ( } 4 \mathrm{mg} / 8 \mathrm{mg} \text { i.v. } \\
\text { every } 3-4 \text { weeks; } 13 \text { months })\end{array}$ & $\begin{array}{l}\text { proportion of patients with at least } 1 \text { SRE was similar in all treatment } \\
\text { groups } \\
\text { median time to the first SRE approximately } 1 \text { year in each treatment } \\
\text { group } \\
\text { zoledronic acid } 4 \mathrm{mg} \text { significantly decreased the incidence and event } \\
\text { rate for radiation therapy to bone } \\
\text { uNTX-levels were significantly lower in the } 4 \text {-mg zoledronic acid group }\end{array}$ \\
\hline Rosen et al., 2004 [26] & 1,130 & $\begin{array}{l}\text { pamidronate ( } 90 \mathrm{mg} \text { i.v.) } \\
\text { vs. zoledronic acid ( } 4 \text { mg i.v.) } \\
\text { every } 3-4 \text { weeks; } 12 \text { months }\end{array}$ & $\begin{array}{l}\text { prolonged time to first SRE ( } 174 \text { vs. } 310 \text { days; } \mathrm{p}=0.013) \\
\text { risk reduction of skeletal events by } 20 \%(\mathrm{HR}=0.801 ; \mathrm{p}=0.037) \\
\text { risk reduction of skeletal events in patients with osteolytic lesions } \\
\text { by } 30 \%(\mathrm{HR}=0.704 ; \mathrm{p}=0.010)\end{array}$ \\
\hline Stopeck et al., 2010 [5] & 2,046 & $\begin{array}{l}\text { zoledronic acid ( } 4 \text { mg i.v.) } \\
\text { vs. denosumab ( } 120 \text { mg s.c.) } \\
\text { every } 4 \text { weeks; } 27 \text { months }\end{array}$ & $\begin{array}{l}\text { delayed time to first on-study } \mathrm{SRE}(\mathrm{HR}=0.82 ; \mathrm{p}<0.0001 \\
\text { non-inferiority; } \mathrm{p}=0.01 \text { superiority) } \\
\text { delayed time to first and subsequent on-study SRE (rate ratio } 0.77 ; \\
\mathrm{p}=0.001) ; \\
\text { delayed time to first radiation to bone }(\mathrm{HR}=0.74 ; \mathrm{p}=0.01) ; \\
\text { delayed time to first on-study SRE or } \mathrm{HCM}(\mathrm{HR}=0.82 ; \mathrm{p}=0.007) ; \\
\text { reduction mean SMR }(0.58 \text { vs. } 0.45, \text { respectively; } \mathrm{p}=0.004) ; \\
\text { reduction of patients experiencing } \geq 1 \text { on-study SRE }(\text { denosumab: } \\
30.7 \%(95 \% \mathrm{CI}, 27.9 \%, 33.5 \%))(\text { zoledronic acid: } 36.5 \%(95 \% \mathrm{CI} \text {, } \\
33.5 \%, 39.4 \%)) \\
\text { overall survival }(\mathrm{HR}, 0.95 ; 95 \% \mathrm{CI}, 0.81 \text { to } 1.11 ; \mathrm{p}=0.49) \text { and disease } \\
\text { progression }(\mathrm{HR}, 1.00 ; 95 \% \mathrm{CI}, 0.89 \text { to } 1.11 ; \mathrm{p}=0.93) \text { similar between } \\
\text { treatment groups } \\
\text { greater suppression of bone turnover markers compared with } \\
\text { zoledronic acid }(\mathrm{p}<0.001)\end{array}$ \\
\hline
\end{tabular}

SMPR = Skeletal morbidity period rate; SMR = skeletal morbidity rate; SRE = skeletal related event; HCM = hypercalcemia of malignancy; $\mathrm{HR}=$ hazard ratio;

$\mathrm{CI}=$ confidence interval.

strong in skeletal regions with increased bone metabolism. Aminobisphosphonates (pamidronate, zoledronic acid, ibandronate) interfere with the mevalonate metabolism, which is responsible, inter alia, for the biosynthesis of cholesterol and its derivatives. Bisphosphonates induce apoptotic processes in the osteoclasts [27] but if they accumulate they can also have the same effect on the intestinal mucosa and on renal tubuli $[28,29]$.

A number of trials have investigated the effect of bisphosphonates in the treatment of bone metastases from breast cancer, albeit with different endpoints [30]. A randomized study showed that the median time to progression in bone was increased by $48 \%$ in patients who received pamidronate (249 vs. 168 days; $p=0.02$ ) and a significant reduction in pain, defined as a two-point decrease lasting for $\geq 6$ weeks (44 vs. $30 \% ; \mathrm{p}=0.025)$ compared to those that received chemotherapy alone [31].

Subsequently, pamidronate was investigated in 2 prospective, multicenter, randomized, double-blind, placebo-controlled intervention trials $[32,33]$ which were combined by Lipton et al. [11] to provide a larger data set. The pooled analysis at 2 years follow-up demonstrated that pamidronate therapy resulted in significant reductions in the percentage of patients with skeletal complications (51 vs. 64\%; p < 0.001). The skeletal 
morbidity rate was 2.4 in the pamidronate group and 3.7 in the placebo group $(\mathrm{p}<0.001)$. Median time to first skeletal complication was about 6 months longer in the pamidronate group compared with placebo (12.7 vs. 7 months; $p<0.001)$ [11].

Ibandronate was evaluated as oral and i.v. formulation. In the phase III trial comparing ibandronate $(6 \mathrm{mg}$ i.v. and $2 \mathrm{mg}$ i.v. administered every 3-4 weeks) to placebo a total of 466 patients were randomized to receive placebo $(\mathrm{n}=158)$, $2 \mathrm{mg}(\mathrm{n}=154)$, or $6 \mathrm{mg}(\mathrm{n}=154)$ ibandronate every $3-4$ weeks for up to 2 years. The primary efficacy parameter was the skeletal morbidity period rate (SMPR), calculated from the number of 12 -week periods with new bone complications. SMPR was statistically significantly lower for the ibandronate $6 \mathrm{mg}$ group compared with placebo $(\mathrm{p}=0.004)$, but not for the ibandronate $2 \mathrm{mg}$ group. In accordance with the SMPR, ibandronate $6 \mathrm{mg}$ significantly decreased the number of new bone events by $38 \%$ and prolonged the time to first new bone event $(\mathrm{p}=0.018)[23]$.

Oral ibandronate $50 \mathrm{mg}$ once daily therapy was assessed in 2 placebo-controlled phase III clinical trials in 564 patients with breast cancer and bone metastases for up to 96 weeks. Patients were randomized to receive oral ibandronate $50 \mathrm{mg}$ $(\mathrm{n}=287)$ or placebo $(\mathrm{n}=277)$. The pooled analysis showed that ibandronate $50 \mathrm{mg}$ significantly reduced the mean skeletal morbidity period rate compared with placebo $(0.95 \mathrm{v} 1.18$; $\mathrm{p}=0.004)$. Moreover, there was a reduction in the risk of a skeletal event compared with placebo (hazard ratio (HR) $0.62,95 \% \mathrm{CI}=0.48,0.79 ; \mathrm{p}=0.0001)$ and the mean number of events requiring surgery $(0.47$ vs. $0.53, \mathrm{p}=0.037)$ or radiotherapy $(0.73$ vs. $0.98, \mathrm{p}<0.001)$ [24].

An international double-blind, randomized, doubledummy parallel-group trial compared zoledronic acid $4 \mathrm{mg}$ $(\mathrm{n}=564), 8 \mathrm{mg}(\mathrm{n}=526)$ and pamidronate $90 \mathrm{mg}(\mathrm{n}=558)$ in patients with advanced breast cancer or multiple myeloma and at least one bone lesion [25]. Criteria for exclusion were bisphosphonate therapy within the last 12 months, hypercalcemia, serum creatinine $>3 \mathrm{mg} / \mathrm{dl}$ and/or bilirubin $>2.5 \mathrm{mg} / \mathrm{dl}$. The primary study endpoint was the proportion of patients with $\geq 1$ SREs after 13 months. As regards SRE prevention, evaluation of the study results showed that zoledronic acid $4 \mathrm{mg}$ and pamidronate were clinically equivalent.

In a large randomized phase III trial by Rosen and colleagues [34] 1,130 patients with breast carcinoma who had bone metastases of all types (osteolytic, mixed, or osteoblastic by radiology) were randomized to receive treatment with either zoledronic acid (4 mg i.v. 15-min infusion every 3-4 weeks) or pamidronate therapy ( $90 \mathrm{mg}$ i.v. 2-h infusion every 3-4 weeks) for 12 months. Both the zoledronic acid group and the pamidronate group showed a reduction of the overall proportion of patients with an SRE (43 vs. $45 \%$ ) to a similar extent; in the subset of patients with at least one osteolytic lesion $(\mathrm{n}=528)$, zoledronic acid reduced the proportion of patients with an SRE compared to pamidronate (48 vs. 58\%), but this did not reach statistical significance $(p=0.058)$. The time to first SRE was significantly prolonged in the $4 \mathrm{mg}$ zoledronic acid group compared with the pamidronate group (310 vs. 174 days; $p=0.013$ ). Furthermore, multiple-event analysis demonstrated a $20 \%$ reduction in the risk of skeletal events $(\mathrm{HR}=0.801 ; \mathrm{p}=0.037)$ with zoledronic acid compared to pamidronate in all patients, with an even greater reduction in the osteolytic subset $(\mathrm{HR}=0.70 ; \mathrm{p}=0.010)$ [34].

\section{Adverse Effects of Bisphosphonates}

The most frequent adverse effects of bisphosphonates include acute-phase reactions [Fachinformation Zometa ${ }^{\circledR}$, as of September 2011; FI Bonviva ${ }^{\circledR}$, as of September 2011], which comprise flu-like symptoms such as subfebrile temperatures, leukocytosis, fatigue and pain in the muscles or bones. These reactions occur predominantly - in up to $30 \%$ of cases - on first infusion of aminobisphosphonates administered intravenously [23, 32, 34].

Very rare adverse effects are gastrointestinal disorders, nephrotoxic complications and jaw bone osteonecrosis (ONJ). Particularly ONJ received extensive (including public) attention. Some authors explain the occurrence of ONJ by pointing out that bisphosphonates and other antiresorptives (including denosumab) may promote pre-existing inflammatory and destructive processes in patients with dental/gingival or jawbone disorders by reducing bone remodeling and on account of their anti-angiogenic and apoptotic properties [35].

Because of bisphosphonates' possible nephrotoxicity patients should be continuously monitored over the course of treatment and the dose administered should be reduced as soon as a creatinine clearance of $30-60 \mathrm{ml} / \mathrm{min}$ is found (zoledronic acid); bisphosphonate therapy is contraindicated in case of a creatinine clearance of $<30 \mathrm{ml} / \mathrm{min}$.

\section{Denosumab: Mechanism of Action and Clinical Findings}

Discovery of the central role played by the OPG/RANKL system in bone metabolism in general and in bone metastasis in particular resulted in the development of denosumab, fully human monoclonal IgG2 antibody which binds to the RANKL with high affinity and specificity [36], thereby preventing RANKL from interacting with its receptor (RANK) on osteoclasts and their precursor stages. Thus, denosumab inhibits osteoclast-mediated bone resorption. This, in turn, reduces the release of growth factors and calcium from the bone matrix while, conversely, inhibiting the secretion of cytokines and growth factors by the tumor which enable the induction of osteoblasts and, accordingly, an increase in the formation of the RANK ligand. As regards the RANK ligand, denosumab imitates the action of OPG in counteracting its action on osteoclasts [36].

Denosumab is the first antibody approved for use to prevent skeletal complications in patients with bone metastases caused by solid tumors. The approved dose is $120 \mathrm{mg}$ every 
4 weeks, and no monitoring of renal function or possible dose modifications (in line with renal function) are necessary. Administration is by subcutaneous (s.c.) injection. To date, clinical phase III trials have revealed no neutralizing antibodies [37].

In the international randomized, double-blind, doubledummy study that formed the basis for approval denosumab (120 mg s.c. + i.v.-placebo infusion every 4 weeks; $\mathrm{n}=1,026)$ was compared with zoledronic acid (4 mg i.v.; adjusted to renal function when necessary + placebo s.c. every 4 weeks; $\mathrm{n}=1,020)$ in the treatment of breast cancer patients with bone metastases (histologically or cytologically verified adenocarcinoma of the breast; ECOG performance status 0, 1, 2) [5]. The primary endpoint was the time to occurrence of the first SREs (non-inferiority), while the secondary endpoints were the superiority as compared with zoledronic acid respecting the time to occurrence of the first SRE and the time to the first and subsequent SREs (multiple event analysis) [38]. The exploratory study endpoints were overall survival, disease progression, skeletal morbidity rates and percentage changes of urinary N-terminal telopeptide (uNTX) and/or bone-specific alkaline phosphatase from the start of the trial to week 13.

Main exclusion criteria were a creatinine clearance of $<30 \mathrm{ml} / \mathrm{min}$ and previous treatment with bisphosphonates i.v. or current bisphosphonate treatment due to bone metastases. The patient population was basically well-balanced (previous SREs, time of diagnosis, hormone receptor status, concomitant hormone or chemotherapy). In this pivotal study, denosumab therapy resulted in a significant delay of the time to first SRE (18\% as compared with zoledronic acid (HR, 0.82; $95 \%$ confidence interval (CI), 0.71-0.95; $\mathrm{p}<0.001$ non-inferiority; $\mathrm{p}=0.01$ superiority), with the therapeutic effect of denosumab remaining constant over the time of the study. The median time to first SRE was 26.4 months in the zoledronic acid arm and has not yet been reached in the denosumab group. Denosumab also significantly reduced the risk of multiple SREs (time to first and subsequent SREs) by $23 \%$ as compared with zoledronic acid (rate ratio, 0.77; $95 \% \mathrm{CI}$, 0.66 to $0.89 ; \mathrm{p}=0.001$ ) and lowered the mean skeletal morbidity rate by $22 \%$ ( 0.45 vs. 0.58 events per patient and year; $\mathrm{p}=0.0004)$.

With regard to overall survival, disease progression and adverse events (Common Terminology Criteria of Adverse Events (CTCAE grade $\geq 3$ or severe) no relevant groupspecific differences were seen. Denosumab achieved a stronger suppression of bone metabolism markers than zoledronic acid: by week 13 the uNTX/creatinine levels had dropped by $80 \%$ under denosumab (vs. $68 \%$ zoledronic acid; $\mathrm{p}<0.001$ [5]).

ONJ were generally rare, but non-significantly increased in the denosumab group (denosumab: $20(2.0 \%)$ vs. zoledronic acid: $14(1.4 \%) ; \mathrm{p}=0.39)$. The cumulative incidence of $\mathrm{ONJ}$ in the s.c. denosumab and i.v. zoledronic acid groups, respectively, was 0.8 and $0.5 \%$ at 1 year, 1.9 and $1.2 \%$ at 2 years, and
2.0 and $1.4 \%$ at 3 years. Acute phase reactions were 2.7 times more frequent under zoledronic acid. Renal side effects were also more frequent with the bisphosphonate (zoledronic acid: $8.5 \%$ vs. denosumab $4.9 \% ; p=0.001)$. Serum calcium reductions were more frequent with denosumab (56 (5.5\%) vs. zoledronic acid: $34(3.4 \%) ; \mathrm{p}<0.05)$ but generally mild and transient. No patients developed detectable levels of neutralizing anti-denosumab antibodies in the s.c. denosumab group.

\section{Conclusions}

Bone metastases are frequently found in cancer patients and often associated with debilitating and cost-intensive skeletal-related events (SREs: pathological fractures, need for radiotherapy and/or surgical interventions, myelonic compression) with a negative effect on mortality risk and quality of life parameters. Current data suggest that denosumab is the most effective substance (regarding time to skeletal events) so far available for the treatment of patients with de novo breast cancer and bone metastases, thus representing a new therapeutic standard for the prevention of skeletal complications. The scientific data have meanwhile lead to the approval of denosumab (XGEVA ${ }^{\circledR}$, Amgen Austria GmbH, Vienna, Austria) in the US and Europe.

While practice-changing valid scientific evidence that would suggest a therapy change in favor of denosumab is still outstanding, such a switch may be contemplated in patients who no longer benefit from zoledronic acid treatment or if zoledronic acid therapy results in renal toxicity (relative indication: creatinine clearance $30-60 \mathrm{ml} / \mathrm{min}$ ).

In order to forestall the relatively rare complication of jawbone osteonecrosis (ONJ) all patients should see a dentist before an antiresorptive therapy with zoledronic acid or denosumab is started, since the frequency of that complication can only be lowered by genuine preventive measures. Whenever ONJ is diagnosed the antiresorptive therapy should be discontinued and a specialized center consulted.

\section{Acknowledgements}

This manuscript is derived in part from other work that was previously coordinated by Update Europe GmbH and supported by Amgen Austria GmbH. Funding for medical writing support for this manuscript was also provided by Amgen Austria GmbH.

\section{Disclosure Statement}

Michael Gnant reports having received research support from GlaxoSmithKline, Sanofi-Aventis, Novartis, Roche. He has served as consultant for Merrion and Novartis, and reports having received honoraria (speak-
96

Breast Care 2012;7:92-98
Gnant/Balic/Petru/Raunik/Singer/

Steger/Watzke/Brodowicz 
ing, advisory boards, etc.) and travel support from Amgen, Pfizer, Novartis, GlaxoSmithKline, Bayer, Sandoz, AstraZeneca, and GenomicHealth. Marija Balic reports having received research support from Amgen, Cephalon and Sanofi-Aventis. She has received honoraria (speaking, advisory boards, etc.) and travel support from Amgen, Roche, Novartis and AstraZeneca. Edgar Petru reports having received honoraria (speaking, advisory boards, etc.) and travel support from SanofiAventis, GlaxoSmithKline, Novartis, Roche, Amgen, Celgene, Sandoz, Ratiopharm, Amgen, Pfizer, Amomed, MSD, and AstraZeneca. Wolfgang Raunik reports having received honoraria (speaking, advisory boards, etc.) and travel support from Amgen, Merck, Novartis, AstraZeneca and Roche. Christian F. Singer reports having received research support from
Novartis, Amgen and Roche and reports having received honoraria and travel support from Amgen, Novartis, GlaxoSmithKline, and AstraZeneca. Guenther G. Steger reports having received research support and consultancy fees from Roche Austria and Amgen, lecture fees, advisory board fees, travel grants, and meeting grants from Amgen, Roche Austria, Hoffmann La-Roche, Sanofi-Aventis, AstraZeneca, GlaxoSmithKline, Novartis, Cephalon, Eisai, and lecture fees from EBEWE and Pfizer. Ingeborg M. Watzke declares there is no conflict of interest. She has no connections what so ever with one of the pharmaceutical companies mentioned. Thomas Brodowicz reports having received lecture fees from Amgen, Novartis. He has received honoraria (advisory boards) from Amgen and Novartis.

\section{References}

$\checkmark 1$ Kinnane N: Burden of bone disease. Eur J Oncol Nurs 2007;11 Suppl 2:S28-31.

$\checkmark 2$ Weinfurt KP, Li Y, Castel LD, Saad F, Timbie JW Glendenning GA, Schulman KA: The significance of skeletal-related events for the health-related quality of life of patients with metastatic prostate cancer. Ann Oncol 2005;16(4):579-84.

3 Ferlay J, Parkin DM, Steliarova-Foucher E: Estimates of cancer incidence and mortality in Europe in 2008. Eur J Cancer 2010;46:765-781.

4 Jakesz R, Jonat W, Gnant M, Mittlboeck M, Greil R, Tausch C, Hilfrich J, Kwasny W, Menzel C, Samonigg H, Seifert M, Gademann G, Kaufmann M, Wolfgang J; ABCSG and the GABG: Switching of postmenopausal women with endocrine-responsive early breast cancer to anastrozole after 2 years' adjuvant tamoxifen: combined results of ABCSG trial 8 and ARNO 95 trial. Lancet 2005;366(9484):455-62.

$\checkmark 5$ Stopeck AT, Lipton A, Body JJ, Steger GG, Tonkin K, de Boer RH, Lichinitser M, Fujiwara Y, Yardley DA, Viniegra M, Fan M, Jiang Q, Dansey R, Jun S, Braun A: Denosumab compared with zoledronic acid for the treatment of bone metastases in patients with advanced breast cancer: a randomized, double-blind study. J Clin Oncol 2010;28(35):5132-9.

6 Coleman R: Potential use of bisphosphonates in the prevention of metastases in early-stage breast cancer. Clin Breast Cancer 2007;7(Suppl 1):S29S35.

7 Coleman RE: Clinical features of metastatic bone disease and risk of skeletal morbidity. Clin Cancer Res 2006;12:6243s-9s.

$>8$ Parkin DM, Bray F, Ferlay J, Pisani P: Global cancer statistics, 2002. CA Cancer J Clin 2005;55(2): 74-108.

-9 Saad F, Olsson C, Schulman CC: Skeletal morbidity in men with prostate cancer: quality-of-life considerations throughout the continuum of care. Eur Urol 2004;46(6):731-39.

10 www.fda.gov/downloads/Drugs/ GuidanceComplianceRegulatoryInformation/ Guidances/ucm071590.pdf (Accessed 2 March 2011).

11 Lipton A, Theriault RL, Hortobagyi GN, Simeone J, Knight RD, Mellars K, Reitsma DJ, Heffernan M, Seaman JJ: Pamidronate prevents skeletal complications and is effective palliative treatment in women with breast carcinoma and osteolytic bone metastases: long term follow-up of two randomized, placebo-controlled trials. Cancer 2000;88(5):1082-90.
12 Kohno N, Aogi K, Minami H, Nakamura S, Asaga T, Ino Y, Watanabe T, Goessl C, Ohashi Y, Takashima S: Zoledronic acid significantly reduces skeletal complications compared with placebo in Japanese women with bone metastases from breast cancer: a randomized, placebo-controlled trial. J Clin Oncol 2005;23(15):3314-21.

13 Kaminski M, Rosen L, Gordon D, Zheng M, Hei YJ: Zoledronic acid versus pamidronate in patients with breast cancer and multiple myeloma who are at high risk for skeletal complications. J Clin Oncol 2004;22, (Suppl):857.

14 Delea T, McKiernan J, Brandman J, Edelsberg J, Sung J, Raut M, Oster G: Retrospective study of the effect of skeletal complications on total medical care costs in patients with bone metastases of breast cancer seen in typical clinical practice. J Support Oncol 2006;4(7):341-7.

15 Saad F, Lipton A, Cook R, Chen YM, Smith M, Coleman R: Pathologic fractures correlate with reduced survival in patients with malignant bone disease. Cancer 2007;110(8):1860-7.

16 Boyle WJ, Simonet WS, Lacey DL: Osteoclast differentiation and activation. Nature 2003;423: $337-342$.

17 Lacey DL, Timms E, Tan HL, Kelley MJ, Dunstan CR, Burgess T, Elliott R, Colombero A, Elliott G, Scully S, Hsu H, Sullivan J, Hawkins N, Davy E, Capparelli C, Eli A, Qian YX, Kaufman S, Sarosi I, Shalhoub V, Senaldi G, Guo J, Delaney J, Boyle WJ: Osteoprotegerin ligand is a cytokine that regulates osteoclast differentiation and activation. Cell 1998;93(2):16576.

18 Hsu H, Lacey DL, Dunstan CR, Solovyev I, Colombero A, Timms E, Tan HL, Elliott G, Kelley MJ, Sarosi I, Wang L, Xia XZ, Elliott R, Chiu L, Black T, Scully S, Capparelli C, Morony S, Shimamoto G, Bass MB, Boyle WJ: Tumornecrosis factor receptor family member RANK mediates osteoclast differentiation and activation induced by osteoprotegerin ligand. Proc Natl Acad Sci 1999; 96:3540-5.

19 Simonet WS, Lacey DL, Dunstan CR, Kelley M, Chang MS, Lüthy R, Nguyen HQ, Wooden S, Bennett L, Boone T, Shimamoto G, DeRose M, Elliott R, Colombero A, Tan HL, Trail G, Sullivan J, Davy E, Bucay N, Renshaw-Gegg L, Hughes TM, Hill D, Pattison W, Campbell P, Sander S, Van G, Tarpley J, Derby P, Lee R, Boyle WJ: Osteoprotegerin: a novel secreted protein involved in the regulation of bone density. Cell 1997;89(2):309-19.
0 Roodman GD: Mechanisms of bone metastasis. N Engl J Med 2004;350:1655-1664.

21 Kitazawa S, Kitazawa R: RANK ligand is a prerequisite for cancer-associated osteolytic lesions. J Pathol 2002;198(2):228-36.

22 Mundy GR: Metastasis to bone: causes, consequences and therapeutic opportunities. Nat Rev Cancer 2002;2(8):584-93.

23 Body JJ, Diel IJ, Lichinitser MR, Kreuser ED, Dornoff W, Gorbunova VA, Budde M, Bergström B; MF 4265 Study Group: Intravenous ibandronate reduces the incidence of skeletal complications in patients with breast cancer and bone metastases. Ann Oncol 2003;14(9):1399-405.

24 Body JJ, Diel IJ, Lichinitzer M, Lazarev A, Pecherstorfer M, Bell R, Tripathy D, Bergstrom B: Oral ibandronate reduces the risk of skeletal complications in breast cancer patients with metastatic bone disease: results from two randomised, placebo-controlled phase III studies. Br J Cancer 2004;90(6):1133-7.

25 Rosen LS, Gordon D, Kaminski M, Howell A, Belch A, Mackey J, Apffelstaedt J, Hussein M, Coleman RE, Reitsma DJ, Seaman JJ, Chen BL, Ambros Y: Zoledronic acid versus pamidronate in the treatment of skeletal metastases in patients with breast cancer or osteolytic lesions of multiple myeloma: a phase III, double-blind, comparative trial. Cancer J 2001;7(5):377-87.

26 Rosen LS, Gordon D, Tchekmedyian NS, Yanagihara R, Hirsh V, Krzakowski M, Pawlicki M, De Souza P, Zheng M, Urbanowitz G, Reitsma D, Seaman J: Long-term efficacy and safety of zoledronic acid in the treatment of skeletal metastases in patients with nonsmall cell lung carcinoma and other solid tumors: a randomized, Phase III, double-blind, placebo-controlled trial. Cancer 2004;100(12):2613-21.

27 Russell RG, Rogers MJ, Frith JC, Luckman SP, Coxon FP, Benford HL, Croucher PI, Shipman C, Fleisch HA: The pharmacology of bisphosphonates and new insights into their mechanisms of action. J Bone Miner Res 1999;14 Suppl 2:53-65.

28 Luckman SP, Hughes DE, Coxon FP, Graham R, Russell G, Rogers MJ: Nitrogen-containing bisphosphonates inhibit the mevalonate pathway and prevent post-translational prenylation of GTPbinding proteins, including Ras. J Bone Miner Res 1998;13(4):581-9.

29 Rogers MJ, Frith JC, Luckman SP, Coxon FP, Benford HL, Mönkkönen J, Auriola S, Chilton KM, Russell RG. Molecular mechanisms of action of bisphosphonates. Bone 1999;24(5 Suppl):73S$79 \mathrm{~S}$. 
30 Pavlakis N, Schmidt R, Stockler M. Bisphosphonates for breast cancer. Cochrane Database Syst Rev 2005:CD003474.

31 Conte PF, Latreille J, Mauriac L, Calabresi F, Santos R, Campos D, Bonneterre J, Francini G Ford JM: Delay in progression of bone metastase in breast cancer patients treated with intravenous pamidronate: results from a multinational random ized controlled trial. The Aredia Multinationa Cooperative Group. J Clin Oncol 1996;14(9): 2552-9.

32 Hortobagyi GN, Theriault RL, Lipton A, Porter L, Blayney D, Sinoff C, Wheeler H, Simeone JF, Seaman JJ, Knight RD, Heffernan M, Mellars K, Reitsma DJ: Long-term prevention of skeletal complications of metastatic breast cancer with pamidronate. Protocol 19 Aredia Breast Cancer Study Group. J Clin Oncol 1998;16(6):2038-44.
33 Theriault RL, Lipton A, Hortobagyi GN, Leff R, Glück S, Stewart JF, Costello S, Kennedy I, Simeone J, Seaman JJ, Knight RD, Mellars K, Heffernan M, Reitsma DJ: Pamidronate reduces skeletal morbidity in women with advanced breast cancer and lytic bone lesions: a randomized, placebo-controlled trial. Protocol 18 Aredia Breast Cancer Study Group. J Clin Oncol 1999;17(3): 846-54.

34 Rosen LS, Gordon DH, Dugan W Jr, Major P, Eisenberg PD, Provencher L, Kaminski M, Simeone J, Seaman J, Chen BL, Coleman RE: Zoledronic acid is superior to pamidronate for the treatment of bone metastases in breast carcinoma patients with at least one osteolytic lesion. Cancer 2004;100(1):36-43.

35 Wood J, Bonjean K, Ruetz S, Bellahcène A, Devy L, Foidart JM, Castronovo V, Green JR: Novel antiangiogenic effects of the bisphosphonate compound zoledronic acid. J Pharmacol Exp Ther 2002;302(3):1055-61.
36 McClung MR, Lewiecki EM, Cohen SB, Bolognese MA, Woodson GC, Moffett AH, Peacock M, Miller PD, Lederman SN, Chesnut CH, Lain D, Kivitz AJ, Holloway DL, Zhang C, Peterson MC, Bekker PJ; AMG 162 Bone Loss Study Group: Denosumab in postmenopausal women with low bone mineral density. N Engl J Med 2006;354(8):821-31.

37 Fachinformation XGEva ${ }^{\circledR}$, as of September 2011: http://ch.oddb.org/de/goc/fachinfo/reg/61865.

38 Stopeck AT, Lipton A, Body JJ, Steger GG, Tonkin K, de Boer RH, Lichinitser M, Fujiwara Y, Yardley DA, Viniegra M, Fan M, Jiang Q, Dansey R, Jun S, Braun A: Denosumab compared with zoledronic acid for the treatment of bone metastases in patients with advanced breast cancer: a randomized, double-blind study. J Clin Oncol 2010;28(35):5132-9. 